\title{
PENGARUH RESIDUAL INCOME DAN MARKET TO BOOK RATIO TERHADAP STOCK RETURN PADA INDUSTRI MANUFAKTUR
}

\author{
Andian Ari Istiningrum dan Suryati \\ aa_istiningrum@yahoo.com, suryati.red@gmail.com \\ Jurusan Pendidikan Akuntansi, Fakultas Ekonomi, Universitas Negeri Yogyakarta
}

\begin{abstract}
The aims of this research are to determine the influence of residual income and market to book ratio toward stock return in the manufacture companies listed in the Bursa Efek Indomesia (BEI) during 2010-2012. The number of population is 135 manufacture companies and 30 manufacture companies based on the criterions are chosen as the research sample. Historical data from 2010 to 2012 is used in this research. Data is analyzed by multiple regression. The research reveals that residual income and market to book ratio individually has a positive and significant influence toward stock return. Market to book ratio is proven as the factor that provides higher influence as compared to residual income.
\end{abstract}

Keywords: stock return, residual income, market to book ratio

PENDAHULUAN

Kompetisi bisnis yang semakin ketat membawa konsekuensi tersendiri bagi perusahaan, yaitu meningkatnya kebutuhan dana perusahaan. Perusahaan bisa mendapatkan dana baik melalui pendanaan dari dalam perusahaan dan pendanaan dari luar perusahaan. Pendanaan dari dalam diperoleh perusahaan melalui modal yang disetorkan oleh pemilik perusahaan, sedangkan bagi perusahaan go public pendanaan diperoleh dari penerbitan saham. Pendanaan dari luar diperoleh perusahaan dengan menerbitkan obligasi atau mendapatkan pinjaman dari lembaga keuangan.
Pasar modal memberi peranan penting bagi perusahaan untuk menawarkan dan memperdagangkan saham kepada masyarakat luas. Investor akan memilih perusahaan yang mampu memaksimalkan nilai perusahaan. Akan tetapi, investor seringkali menghadapi permasalahan bahwa nilai perusahaan pada masa mendatang cenderung memiliki tingkat ketidakpastian yang tinggi (Trisnawati 2009). Ketika perusahaan berhasil mendapatkan laba, nilai pasar saham perusahaan cenderung meningkat yang tentu saja hal ini akan menguntungkan investor; sedangkan nilai utang perusahaan tidak terpengaruh sehingga posisi kreditur juga tidak 
terpengaruh (Pradhono dan Christiawan 2004). Sebaliknya, ketika perusahaan menderita rugi, kreditur lebih diutamakan dibandingkan investor. Perusahaan diwajibkan untuk menunaikan kewajibannya terlebih dahulu kepada kreditur, padahal pada saat yang sama nilai saham perusahaan mengalami penurunan (Pradhono dan Christiawan 2004). Oleh karena itu, investor dihadapkan pada permasalahan tingginya risiko yang harus dihadapi ketika memutuskan untuk membeli saham perusahaan.

Investor menginginkan agar perusahaan bisa menyampaikan informasi secara terbuka sehingga informasi ini bisa digunakan oleh investor untuk membuat keputusan investasi yang tepat. Untuk memberikan rasa aman terhadap investor, perusahaan diwajibkan untuk menyampaikan informasi mengenai posisi keuangan dan kinerja operasional melalui laporan keuangan. Laporan keuangan akan membantu investor untuk meramalkan nilai perusahaan di masa mendatang (Kieso dkk. 2011).

Investor secara rasional akan melakukan analisis terhadap laporan keuangan perusahaan dengan tujuan agar investor mendapatkan return maksimal dari saham yang dibeli investor dengan mempertimbangkan tingkat risiko yang muncul dari investasi saham tersebut. Pendekatan dengan cara demikian disebut dengan analisis fundamental. Dengan pendekatan ini, investor akan menilai kinerja keuangan perusahaan dengan tujuan agar dapat membandingkan nilai intrinsik saham dengan harga pasarnya (Halim 2005). Analisis fundamental penting dilakukan untuk mengetahui apakah harga pasar saham sudah mencerminkan nilai intrinsik saham saat ini dan mencerminkan peningkatan nilai perusahaan di masa mendatang (Tinneke 2007).

Nilai perusahaan diukur dari nilai saham perusahaan. Stock return yang diterima investor merupakan indikator yang tepat untuk menilai saham perusahaan (Pradhono dan Christiawan 2004). Return yang diterima investor bisa berupa kenaikan harga saham pada suatu periode dan penerimaan dividen tunai (Ross et al. 2002). Namun, tidak bisa dipungkiri bahwa untuk mendapatkan return yang tinggi, risiko yang dihadapi juga tinggi. Return dan risiko memiliki hubungan positif dimana semakin tinggi return maka risiko yang dihasilkan juga semakin tinggi. Sebaliknya, semakin rendah risiko yang dihadapi investor, return yang diterima investor juga semakin rendah (Hartono 2010).

Stock return yang diterima investor cenderung sulit untuk diprediksi karena nilainya yang fluktuatif. Pada tahun 2008 terjadi penurunan signifikan stock return pada perusahaan manufaktur sebesar 
70,63\%. Di tahun berikutnya, stock return naik sebesar 55,29\% (BEI 2009). Harga pasar saham yang merupakan salah satu unsur pembentuk stock return tidak mudah diramalkan jika kondisi pasar tidak stabil. Demikian juga dengan dividen tunai yang pembayarannya selain ditentukan oleh besarnya laba perusahaan juga ditentukan oleh kebijakan manajemen perusahaan.

Investor oleh karena itu perlu melakukan analisis fundamental terhadap kinerja perusahaan terlebih dahulu sehingga investor dapat mengambil keputusan investasi terbaik untuk mendapatkan return yang diharapkan dengan risiko yang dapat ditoleransi.

Residual income merupakan salah satu faktor yang perlu dipertimbangkan dalam memprediksi besarnya stock return yang diterima investor. Residual income seringkali dipandang lebih memberikan makna bagi investor dibandingkan dengan return on investment (ROI). Residual income mampu memberikan informasi kepada investor untuk memilih Penelitian lain yang dilakukan oleh Pradhono dan Christiawan (2004) dan Trisnawati (2009) memberikan hasil yang berbeda dengan Tiswiyanti (2011). Kedua penelitian tersebut ternyata menunjukkan bahwa residual income tidak berpengaruh signifikan terhadap stock return. Hubungan residual income dengan stock return pada kedua penelitian tersebut investasi pada perusahaan yang mampu menghasilkan laba yang melebihi biaya modalnya (Siegel dan Shim 2000). Investor akan memilih perusahaan dengan residual income yang positif karena perusahaan yang demikian mampu memberikan nilai lebih bagi investor, yaitu opportunity cost berupa biaya modal yang ditanggung investor berhasil ditutup oleh laba yang dihasilkan perusahaan.

Tiswiyanti

dalam penelitiannya berhasil membuktikan bahwa residual income berpengaruh positif dan signifikan terhadap stock return yang berarti bahwa semakin tinggi residual income maka semakin tinggi pula stock return yang akan diterima investor. Penelitian tersebut juga memberikan tambahan informasi bahwa dalam kurun waktu 2008-2009, beberapa perusahaan yang terdaftar dalam LQ 45 mengalami penurunan residual income yang cukup signifikan sehingga investor perlu berhatihati untuk menanamkan modal pada perusahaan tersebut.

menunjukkan bahwa residual income tidak mencerminkan tambahan kekaaan bagi investor (Pradhono dan Christiawan 2004). Hasil ini tentu saja bertentangan dengan teori yang disampaikan oleh Siegel dan Shim (2000) yang menyatakan bahwa residual income lebih mencerminkan kemakmuran investor dibandingkan dengan ROI. 
Faktor lain yang tidak kalah penting untuk diperhatikan investor adalah rasio pasar. Rasio pasar mencerminkan penilaian investor terhadap semua aspek kinerja perusahaan baik dari hasil masa lalu maupun hasil yang diharapkan di masa mendatang (Brigham dan Houston 2009). Salah satu tolak ukur dari rasio pasar adalah market to book ratio. Rasio ini merupakan perbandingan antara harga pasar saham dengan nilai buku saham (Gitman 2009). Market to book ratio dipandang sebagai rasio yang bisa digunakan untuk memprediksi stock return karena menggunakan proksi harga pasar saham dalam pengukurannya. Semakin tinggi harga pasar saham, maka perusahaan semakin berhasil menciptakan nilai bagi investor sehingga keuntungan yang diperoleh investor juga meningkat (Fama dan French 1995; Sartono 2001).

Beberapa penelitian secara empiris berhasil membuktikan bahwa fakta di lapangan mengenai market to book ratio sejalan dengan teori yaitu berpengaruh positif terhadap stock return (Nathaniel 2008; Margaretha dan Damayanti 2008; Putri 2012). Akan tetapi ada juga penelitian yang memberikan hasil sebaliknya yaitu market to book ratio tidak berpengaruh terhadap stock return (Dewi 2005). Hasil lain bahkan menunjukkan jika market to book ratio berpengaruh negatif terhadap stock return (Fitriani 2001; Utama dan Yulianto 1998).

Hal-hal di atas menunjukkan bahwa phenomenon gap dan research gap mengenai pengaruh residual income dan market to book ratio terhadap stock return masih banyak terjadi. Oleh karena itu, penelitian lanjutan mengenai kedua prediktor stock return tersebut masih perlu dilakukan pada periode waktu selanjutnya.

Atas dasar latar belakang permasalahan di atas, maka penelitian ini dilakukan dengan tujuan untuk mengetahui pengaruh residual income dan market to book ratio secara individual terhadap stock return yang diterima pemegang saham. Selain itu, penelitian ini juga bertujuan untuk mengetahui tolak ukur mana yang memiliki pengaruh signifikan terhadap stock return apakah residual income yang mewakili kemampuan perusahaan menciptakan nilai tambah bagi investor ataukah market to book ratio yang mewakili rasio pasar perusahaan.

\section{LANDASAN TEORI DAN}

\section{PENGEMBANGAN HIPOTESIS}

\section{Stock Return}

Investasi merupakan penempatan sejumlah dana pada saat ini dengan harapan dapat memperoleh keuntungan di masa mendatang (Husnan dan Hermanto 1998). Keuntungan di masa 
mendatang merupakan syarat mutlak yang yang dipertimbangkan investor sebelum membuat keputusan investasi (Ang 1997). Keuntungan inilah yang sering disebut sebagai return dari suatu investasi. Return merupakan tingkat laba dari suatu investasi, atau bisa juga diartikan sebagai reward atas investasi yang dilakukan investor (Gitman dan Joehnk 2008).

Salah satu jenis investasi yang bisa dilakukan oleh investor adalah dengan membeli saham yang diterbitkan suatu perusahaan. Saham (stock) didefinisikan sebagai tanda penyertaan modal seseorang atau badan usaha dalam suatu perusahaan atau perseroan terbatas (Tjiptono dan Hendy 2006). Investor akan membeli saham perusahaan jika investor yakin bahwa mereka akan mendapatkan return di masa mendatang yang setimpal dengan risiko yang ditanggung investor.

Stock return terdiri atas capital gain (loss) dan yield (Hartono 2010). Capital gain (loss) merupakan keuntungan (kerugian) bagi investor yang diperoleh dari kelebihan harga jual (harga beli) di atas harga beli (harga jual) yang kedunya terjadi di pasar sekunder (Halim 2005). Capital gain (loss) juga dapat diartikan sebagai kenaikan (penurunan) suatu surat berharga (termasuk saham) yang dapat memberikan keuntungan (kerugian) bagi investor (Tandelilin 2007). Formula yang dapat digunakan untuk menentukan capital gain (loss) menurut Hartono (2010) adalah sebagai berikut:

$$
\text { Capital gain }(\text { loss })=\frac{P_{t}-P_{t-1}}{P_{t-1}}
$$

Jika harga saham sekarang $(P t)$ lebih tinggi daripada harga saham periode sebelumnya (Pt-1) maka terjadi capital gain. Sebaliknya jika harga saham periode sebelumnya (Pt-1) lebih tinggi dari harga saham periode sekarang $(P t)$ maka terjadi capital loss (Hartono 2010)

$$
\text { Harga saham cenderung }
$$
berfluktuasi dari suatu periode ke periode berikutnya. Penyebab perubahan harga saham seringkali dikelompokkan ke dalam dua teori yaitu Capital Asset Pricing Model (CAPM) dan Arbitrage Pricing Theory (APT). Kedua model tersebut membahas tentang hubungan antara return dan risiko. CAPM mendasarkan pada satu variabel beta untuk menggambarkan risiko; sedangkan APT menggunakan banyak variabel pengukur risiko (Putri 2012). CAPM memiliki beberapa kelemahan sehingga tidak banyak digunakan dalam menentukan perubahan harga saham. Kelemahan tersebut antara lain (1) risk free berfluktuasi dan berkorelasi dengan return pasar sehingga terjadi bias dalam penaksiran, dan (2) beta merupakan satusatunya faktor yang menjelaskan return sekuritas berisiko (Effendi dan Muafi 2001). 
Pendekatan APT menjadi dasar yang digunakan dalam penelitian ini untuk menentukan perubahan harga pasar saham. Pendekatan APT mendasarkan diri pada konsep bahwa perubahan harga pasar saham sangat dipengaruhi oleh permintaan dan penawaran saham di pasar modal dimana permintaan dan penawaran ini sangat tergantung pada ekspektasi dari investor (Weston dan Copeland 1995). Ekspektasi investor untuk melakukan perdagangan saham selain ditentukan oleh kondisi perekonomian dan pasar juga dipengaruhi oleh nilai perusahaan itu sendiri (Ross et al. 2002; Sartono 2001).

Komponen pembentuk stock return berikutnya adalah yield. Yield merupakan presentasi penerimaan kas periodik terhadap harga investasi periode tertentu dari suatu investasi (Halim 2005). Yield dapat juga didefinisikan sebagai komponen return yang mencerminkan aliran kas atau pendapatan yang diperoleh secara periodik dari suatu kegiatan investasi (Hartono 2010). Yield merupakan hasil persentasi dividen terhadap harga saham periode sebelumnya (Hartono 2010). Yield bisa dihitung dengan menggunakan formula sebagai berikut:

$$
\text { Yield }=\frac{D_{t}}{P_{t-1}}
$$

(Hartono 2010)
$D t$ merupakan dividen tunai yang dibayarkan perusahaan kepada investor; sedangkat Pt-1 merupakan harga saham pada tahun sebelum dividen tunai dibayarkan

Secara keseluruhan stock return merupakan penjumlahan dari capital gain (loss) dan yield sehingga diperoleh formula akhir sebagai berikut:

$$
\text { Stock Return }=\frac{P_{t}-P_{t-1}+D_{t}}{P_{t-1}}
$$

(Hartono 2010)

Residual Income

Residual income adalah laba operasi bersih yang diperoleh pusat investasi di atas imbas hasil minimum yang dimintas atas aktiva operasi yang digunakan (Garrison dkk. 2007 dalam Mardani 2013). Definisi lain dari residual income adalah pendapatan operasional yang mampu diperoleh pusat investasi di atas return minimum dari asetnya (Siegel dan Shim 2000). Residual income menggambarkan sejauh mana perusahaan mampu mencapai laba bersih melebihi target laba perusahaan atau dengan kata lain residual income menunjukkan kelebihan nilai laba bersih di atas nilai normalnya (Yudhira 2008).

Pengukuran kinerja keuangan perusahaan dengan menggunakan residual income menghasilkan informasi yang lebih dapat diandalkan dibandingkan dengan return on investment (ROI) karena residual income memberikan informasi kepada 
investor untuk memilih investasi yang menghasilkan laba yang mampu menutup biaya modal yang ditanggung investor (Siegel dan Shim 2000). Laba semata tidak cukup bagi investor karena investor tidak akan mendapatkan nilai tambah jika ternyata biaya modal investor tidak dapat ditutup oleh laba perusahaan.

Residual income perusahaan dapat diukur dengan menggunakan formula sebagai berikut:

Residual income $=$ NOPAT $-(k *$ capital $)$

dimana:

NOPAT $=\quad$ laba operasi setelah pajak

$\mathrm{k}=$ biaya modal rata-rata perusahaan (Weighted Average Cost of Capital/WACC).

capital $=$ aktiva tetap yang diinvestasikan dalam aktvitas operasi perusahaan yang berkelanjutan.

(Pradhono dan Christiawan 2004).

Investor diharapkan memilih perusahaan yang memiliki residual income bernilai positif karena hal ini menunjukkan terdapat selisih dana antara dana yang dibutuhkan kreditur dengan modal pemilik (Pradhono dan Christiawan 2004). Perusahaan dengan nilai residual income positif mengindikasikan bahwa perusahaan tersebut mampu menciptakan kemakmuran bagi investor dan sebalikya nilai residual income negatif menunjukkan terjadinya penurunan kemakmuran investor (Pradhono dan Christiawan 2004).

Semakin tinggi residual income suatu perusahaan menunjukkan perusahaan memiliki kinerja yang baik karena perusahaan berhasil mendapatkan laba melebihi jumlah dana yang dikenakan atas pusat investasinya. Dalam kondisi demikian, pasar cenderung akan merespon kenaikan residual income perusahaan sehingga harga saham perusahaan akan naik. Selain itu, dengan meningkatnya residual income memungkinan investor untuk menerima pembayaran dividen tunai dari perusahaan (Tiswiyati 2011). Penelitian dari Tiswiyati (2011) berhasil membuktikan bahwa residual income berpengaruh positif terhadap stock return. Oleh karena itu, semakin tinggi residual income yang dicapai perusahaan, semakin tinggi pula stock return yang diterima investor.

Berdasarkan kajian teoritis dan penelitian sebelumnya, hipotesis yang dikembangkan dalam penelitian ini adalah

H1 : Residual income berpengaruh positif terhadap stock return yang diterima investor.

\section{Market to Book Ratio}

Market to book ratio merupakan rasio perbandingan antara harga pasar per lembar saham dengan nilai buku saham 
pada suatu perusahaan (Gitman 2009). Jika nilai market to book ratio meningkat, maka hal ini mengindikasikan bahwa nilai saham perusahaan dihargai di atas nilai bukunya (Nathaniel 2008) atau dengan kata lain nilai perusahaan di mata investor akan meningkat (Martono 2009). Semakin tinggi nilai perusahaan akan menyebabkan harga pasar saham juga mengalami kenaikan sehingga stock return pada akhirnya turut mengalami peningkatan (Nathaniel 2008; Arista 2012).

Pada saat nilai market to book ratio mengalami penurunan, maka harga saham perusahaan menjadi lebih rendah dari nilai bukunya dan harga saham perusahaan akan dinilai terlalu rendah (undervalued) jika dibandingkan dengan harga saham lain yang sejenis. Pada kondisi demikian, investor akan melakukan pembelian saham. Hal tersebut akan menciptakan kesempatan bagi investor untuk mendapatkan capital gain ketika dikemudian hari harga pasar saham perusahaan mengalami kenaikan (Margaretha dan Damayanti 2008; Prasetya 2000). Oleh karena itu, semakin tinggi nilai market to book ratio, maka semakin tinggi pula stock return yang akan diterima investor. Dengan demikian, hipotesis yang dikembangkan dalam penelitian ini adalah

H2 = Market to book ratio berpengaruh positif terhadap stock return yang diterima investor.

\section{METODE PENELITIAN}

Desain Penelitian

Penelitian ini berdasarkan karakteristik permasalahannya merupakan penelitian kausal komparatif. Penelitian kausal komparatif adalah penelitian yang menunjukkan hubungan yang bersifat sebab akibat (Sugiyono 2011). Penelitian ini juga merupakan penelitian ex post facto dimana peneliti meneliti peristiwa yang telah terjadi dan kemudian merunut ke belakang untuk mengetahui faktor-faktor yang dapat menyebabkan timbulnya kejadian tersebut (Sugiyono 2011).

Atas dasar desain penelitian tersebut, terdapat dua jenis variabel yang digunakan dalam penelitian ini, yaitu variabel dependen dan variabel independen. Variabel dependen adalah stock return; sedangkan variabel independennya adalah residual income dan market to book ratio.

Definisi Operasional Variabel

Tabel 1. Variabel Penelitian 


\begin{tabular}{|c|c|c|}
\hline Variabel & Definisi & Pengukuran \\
\hline $\begin{array}{l}\text { Stock return } \\
\text { (SR) }\end{array}$ & $\begin{array}{llr}\text { Hasil yang } & \text { diperoleh } \\
\text { investor dari } & \text { kegiatan } \\
\text { investasi saham. } & \end{array}$ & $\begin{array}{l}\text { Stock Return }=\frac{P_{t}-P_{t-1}+D_{t}}{P_{t-1}} \\
\text { Harga pasar saham yang digunakan } \\
\text { adalah harga penutupan pada saat } \\
\text { laporan keuangan diterbitkan yaitu } \\
\text { tanggal } 31 \text { Desember }\end{array}$ \\
\hline $\begin{array}{l}\text { Residual income } \\
\text { (Resid) }\end{array}$ & $\begin{array}{l}\text { Pendapatan operasional } \\
\text { yang diperoleh perusahaan } \\
\text { di atas return minimal dari } \\
\text { aset. }\end{array}$ & Residual income $=$ NOPAT $-(k x$ capital $)$ \\
\hline $\begin{array}{l}\text { Market to book ratio } \\
\text { (MtB) }\end{array}$ & $\begin{array}{l}\text { Perbandingan antara harga } \\
\text { pasar per lembar saham } \\
\text { dengan nilai buku per } \\
\text { lembar saham }\end{array}$ & $M t B=\frac{\text { harga pasar per lembar saham biasa }}{\text { nilai buku per lembar biasa }}$ \\
\hline
\end{tabular}

Populasi dan Sampel

Populasi dalam penelitian ini adalah perusahaan manufaktur yang terdaftar di Bursa Efek Indonesia periode 2010 - 2012 dimana populasinya sejumlah 135 perusahaan. Sampel ditentukan dengan purposive sampling dimana kriteria yang digunakan adalah sebagai berikut:

Perusahaan bergerak pada industri manufaktur yang terdaftar di Bursa Efek Indonesia selama tiga tahun berturutturut dari tahun 2010 sampai dengan 2012.

Perusahaan manufaktur menerbitkan laporan keuangan selama tiga tahun berturut-turut dari tahun 2010 sampai dengan 2012.

Perusahaan maufaktur membagikan dividen kas selama tiga tahun berturutturut dari tahun 2010 sampai dengan 2012.
Perusahaan mempublikasikan data yang dibutuhkan untuk menentukan nilai variabel-variabel penelitian selama tiga tahun berturut-turut dari tahun 2010 sampai dengan tahun 2012.

Perusahaan manufaktur yang memenuhi kriteria di atas yaitu sejumlah 30 perusahaan sehingga total terdapat 90 data pengamatan yang digunakan dalam penelitian ini.

\section{Teknik Analisis Data}

Uji hipotesis dilakukan dengan menggunakan model regresi linier berganda dengan persamaan regresi sebagai berikut:

$S R=a+\beta 1$ Resid $+\beta 2 M t B+\varepsilon$

dimana

$\mathrm{SR} \quad=\quad$ stock return

Resid = residual income

$\mathrm{Mtb}=$ market to book ratio

$\alpha=\quad$ konstanta 
$\beta \mathrm{i} \quad=\quad$ koefisien regresi

$\varepsilon=\quad$ error term model

Pengambilan kesimpulan mengenai penerimaan atau penolakan hipotesis penelitian dilakukan dengan menggunakan uji t. Hipotesis penelitian diterima jika tingkat $\operatorname{sig} \mathrm{t}<\mathrm{a}=0,05$.

Uji asumsi klasik yang terdiri atas uji normalitas, uji linearitas, uji multikolinearitas, uji heteroskedastisitas, dan uji autokorelasiterlebih dahulu dilaksanakan. Jika keseluruhan uji tersebut dipenuhi, maka uji hipotesis dengan model regresi linier berganda bisa dilakukan.

\section{HASIL PENELITIAN DAN \\ PEMBAHASAN}

Statistik Deskriptif

Tabel 2 di bawah ini memperlihatkan nilai minimal dan maksimal, rata-rata, dan standar deviasi dari masing-masing variabel penelitian.

Tabel 2. Statistik Deskriptif Variabel Penelitian

\begin{tabular}{|c|c|c|c|c|}
\hline Variabel & Min & Max & $\begin{array}{l}\text { Rata- } \\
\text { rata }\end{array}$ & $\begin{array}{l}\text { Std. } \\
\text { Deviasi }\end{array}$ \\
\hline $\begin{array}{l}\text { Stock } \\
\text { return }\end{array}$ & $(66.400)$ & 36.000 & 2.383 & 10.526 \\
\hline $\begin{array}{l}\text { Residual } \\
\text { income }\end{array}$ & (2.805) & 9.910 & 810 & 1.705 \\
\hline $\begin{array}{l}\text { Market } \\
\text { to book } \\
\text { ratio }\end{array}$ & 0,51 & 2.085 & 147 & 384 \\
\hline
\end{tabular}

Nilai stock return terendah sebesar (66.400) mengindikasikan bahwa investor mengalami kerugian dari investasi saham yang dilakukan. Nilai stock return tertinggi adalah 36.000 yang berhasil dicapai oleh PT Merck Tbk. Rata-rata stock return pada perusahaan manufaktur adalah sebesar 2.383 yang mengindikasikan trend harga pasar saham pada perusahaan manufaktur mengalami kenaikan.

\begin{tabular}{llrr}
\multicolumn{2}{r}{ Nilai minimum } & residual income \\
adalah sebesar & -2.805 & yang \\
mengindikasikan & bahwa & terjadi
\end{tabular}

penurunan kekayaan investor yang melakukan investasi saham pada perusahaan tersebut. Nilai maksimum residual income adalah sebesar 9.910 berarti bahwa perusahaan mampu memaksimalkan kemakmuran investor dimana residual income tertinggi berhasil diraih oleh PT Merck Tbk. Rata-rata residual income yang berhasil dibukukan perusahaan manufaktur adalah 810 . Rerata yang bernilai positif tersebut menunjukkan bahwa rata-rata perusahaan manufaktur mampu meningkatkan 
kekayaan investor yang melakukan investasi saham pada perusahaan manufaktur.

Nilai terendah untuk variabel market to book ratio adalah 0,51 . Nilai market to book ratio ini lebih kecil dari 1 sehingga hal ini menjadi indikasi bahwa investor menilai aktivitas operasi perusahaan berjalan kurang baik sehingga harga pasar sahamnya menjadi lebih rendah dari nilai buku saham. Nilai market to book ratio tertinggi yaitu sebesar 2.085 berhasil dicapai oleh PT Unilever Indonesia Tbk. Rata-rata nilai market to book ratio sebesar 147 memiliki nilai lebih besar dari 1 . Hal ini menunjukkan bahwa rata-rata perusahaan manufaktur menjalankan aktivitasnya dengan baik sehingga investor menilai tinggi kinerja perusahaan relatif terhadap dana yang ditanamkan investor pada perusahaan manufaktur.

Uji Asumsi Klasik

Uji asumsi klasik yang pertama kali dilakukan adalah uji normalitas. Uji normalitas pada penelitian ini dilakukan dengan menggunakan uji Kolmogorov Smirnov. Data terlebih dahulu ditransformasi ke logaritma natural. Hal ini disebabkan asumsi normalitas tidak terpenuhi dengan menggunakan nilai data asli. Tabel 3 di bawah ini menunjukkan hasil uji Kolmogorov Smirnov dengan menggunakan logaritma natural.

Tabel 3. Hasil Uji Kolmogorov Smirnov

\begin{tabular}{llll}
\hline & LN_SR & LN_Resid & LN_MtB \\
\hline $\begin{array}{l}\text { Kolmogorov- } \\
\text { Smirnov Z }\end{array}$ & 0,662 & 1,124 & 1,120 \\
\hline $\begin{array}{l}\text { Asymp. Sig. } \\
\text { (2-tailed) }\end{array}$ & 0,773 & 0,160 & 0,163 \\
\hline \multicolumn{2}{c}{ Sumber: (data diolah) } & &
\end{tabular}

Signifikansi variabel stock return, residual income, dan market to book ratio masing-masing lebih besar dari $a=0,05$ sehigga dapat ditarik kesimpulan bahwa data terdistribusi secara normal.

Uji asumsi klasik kedua adalah uji linearitas. Uji linearitas dalam penelitian ini menggunakan uji Lagrange Multiplier. Berdasarkan hasil uji Lagrange Multiplier, diperoleh nilai koefisien determinasi $\left(\mathrm{R}^{2}\right)$ sebesar 0,551 sehingga besar $\mathrm{C}^{2}$ hitung $=\mathrm{n}$ $x R^{2}=90 \times 0,551=49,59$. Nilai $C^{2}$ hitung $(49,59)<C^{2}$ tabel $(113,145)$ sehingga dapat disimpulkan bahwa model regresi linier bisa digunakan.

Uji asumsi klasik yang ketiga adalah uji multikolinearitas. Uji multikolinearitas dilakukan dengan melihat nilai Variance Inflation Factor (VIF) dan tolerance. Jika nilai VIF $<10$ dan nilai tolerance $>0,1$ 
maka tidak terjadi gejala multikolinearitas

menunjukkan

ha

pada model regresi. Tabel 4 berikut ini

sil uji multikolinearitas.

Tabel 4. Hasil Uji Multikolinearitas

\begin{tabular}{lll}
\hline & Tolerance & VIF \\
\hline LN_Resid & 0,768 & 1,302 \\
\hline LN_MtB & 0,768 & 1,302 \\
\hline \multicolumn{2}{c}{ Sumber: (data diolah) }
\end{tabular}

Dari tabel di atas diperoleh informasi bahwa nilai VIF variabel residual income dan market to book ratio lebih kecil dari 10; sedangkan nilai tolerance kedua variabel tersebut lebih besar dari 0,1 sehingga dapat disimpulkan bahwa tidak

terjadi gejala multikolinearitas pada model regresi.

Uji asumsi klasik yang keempat adalah uji heteroskedastisitas. Uji heteroskedastisitas dalam penelitian ini mengguakan grafik scatterplot.

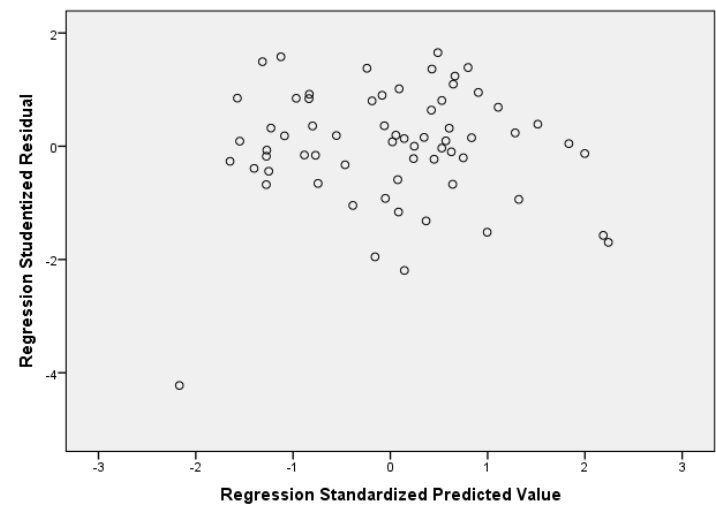

Gambar 1. Hasil Uji Heteroskedastisitas

$\begin{array}{lll}\text { Dari } & \text { gambar } & 1\end{array}$

scatterplot membentuk pola yang tidak teratur sehingga dapat disimpulkan bahwa tidak terjadi gejala heteroskedastisitas.

Uji asumsi klasik yang terakhir adalah uji autokorelasi. Uji autokorelasi pada penelitian ini menggunakan uji Durbin Watson. Nilai Durbin Watson yang dapat dilihat bahwa diperoleh adalah sebesar 1,360. Jika nilai Durbin Watson hitung pada signifikansi 0,05 terletak diantara -2 dan 2, maka model regresi tidak mengandung autokorelasi. Nilai Durbin Watson sebesar 1,360 dalam penelitian ini terletak diantara -2 dan 2 sehingga dapat 
disimpulkan bahwa autokorelasi tidak terjadi pada model regresi.

Uji Hipotesis
Tabel 5 di bawah ini memperlihatkan ringkasan hasil pengolahan data dengan menggunakan program SPSS.

Tabel 5. Koefisien Regresi dan Beta

\begin{tabular}{|c|c|c|c|}
\hline & \multicolumn{2}{|c|}{$\begin{array}{l}\text { Unstandardized } \\
\text { Coefficients }\end{array}$} & \multirow{2}{*}{$\begin{array}{l}\text { Standardized } \\
\text { Coefficients } \\
\text { (Beta) }\end{array}$} \\
\hline & B & Std. Error & \\
\hline Constant & 2,038 & 0,683 & \\
\hline LN_Resid & 0,355 & 0,133 & 0,261 \\
\hline LN_MtB & 0,771 & 0,130 & 0,580 \\
\hline
\end{tabular}

Sumber: (data diolah)

Persamaan regresi yang dapat dibentuk dari tabel 5 di atas adalah sebagai berikut:

LN SR $=2,038+0,355$ LN Resid + 0,771 LN MtB

Koefisien regresi residual income bernilai positif yaitu sebesar 0,355 . Hal ini mengindikasikan bahwa semakin tinggi residual income yang berhasil dicapai perusahaan manufaktur maka akan semakin tinggi pula stock return yang diterima investor. Dengan kata lain, terdapat hubungan positif antara residual income dengan stock return.

Koefisien regresi market to book ratio juga bertanda positif yaitu sebesar 0,771.
Hal ini menunjukkan bahwa semakin tinggi market to book ratio dari suatu perusahaan, maka stock return yang diterima investor juga akan semaking tinggi. Dengan demikian, market to book ratio memiliki hubungan positif dengan stock return.

Nilai koefisien determinan sebagaimana ditunjukkan pada tabel 6 adalah sebesar 0,551 yang berarti bahwa $55,1 \%$ variasi pada variabel stock return dapat dijelaskan oleh variabel residual income dan market to book ratio. Variabel lain yang tidak dimasukkan ke dalam model ini memberikan kontribusi sebesar $44.9 \%$.

Tabel 6. Koefisien Determinan

\begin{tabular}{llll}
\hline Model & $\mathrm{R}$ & $\begin{array}{l}\mathrm{R} \\
\text { Square }\end{array}$ & $\begin{array}{l}\text { Adjusted } \\
\text { Square }\end{array}$ \\
\hline 1 & 0,742 & 0,551 & 0,536 \\
\hline \multicolumn{4}{c}{ Sumber: (data diolah) }
\end{tabular}


Uji hipotesis penelitian 1 dan 2 untuk mengetahui apakah residual income dan market to book ratio secara individual berpengaruh positif signifikan terhadap stock return dilakukan dengan menggunakan t-test. Tabel 7 di bawah ini menunjukkan ringkasan hasil uji hipotesis.

Tabel 7. Ringkasan Hasil Uji Hipotesis

\begin{tabular}{llll}
\hline Variabel & $\begin{array}{l}\mathrm{t} \\
\text { hitung }\end{array}$ & Sig & $\begin{array}{l}\text { Kesimpula } \\
\mathrm{n}\end{array}$ \\
\hline $\begin{array}{l}\text { LN_Resi } \\
\mathrm{d}\end{array}$ & 2,663 & 0,010 & Signifikan \\
LN_MtB & 5,925 & 0,000 & Signifikan \\
\hline \multicolumn{3}{c}{ Sumber: (data diolah) }
\end{tabular}

Berdasarkan tabel 7 di atas, dapat dilihat bahwa tingkat signifikansi variabel residual income adalah sebesar 0,010 dimana nilai ini lebih kecil dari $a=0,05$. Oleh karena itu, H1 dapat diterima yang berarti bahwa residual income berpengaruh positif dan signifikan terhadap stock return.

Tabel 7 juga memberikan informasi bahwa tingkat signifikansi variabel market to book ratio adalah sebesar 0,000 dimana tingkat signifikansi ini lebih kecil dari $a=$ 0,05. Dengan demikian, dapat disimpulkan bahwa $\mathrm{H} 2$ dapat diterima yang berarti bahwa market to book ratio berpengaruh positif dan signifikan terhadap stock return.

Untuk mengetahui variabel mana yang lebih berpengaruh terhadap stock return dapat dilihat dengan menggunakan koefisien beta pada tabel 5. Koefisien beta pada variabel market to book ratio $(0,580)$ lebih besar daripada variabel residual income $(0,261)$ sehingga dapat ditarik kesimpulan bahwa variabel market to book ratio lebih berpengaruh terhadap stock return jika dibandingkan dengan residual income.

Pengaruh Residual Income terhadap Stock Return

Penelitian ini berhasil membuktikan bahwa residual income secara signifikanberpengaruh positif terhadap stock return. Hasil penelitian ini mendukung penelitian yang dilakukan oleh Tiswiyati (2011).

Residual income memberikan informasi untuk memilih investasi yang menghasilkan lebih banyak laba daripada biaya modalnya (Siegel dan Shim 2000). Perusahaan yang memiliki residual income positif menunjukkan bahwa perusahaan tersebut memiliki kelebihan laba yang 
dibutuhkan oleh kreditor dan investor (Pradhono dan Christiawan 2004). Dengan kata lain, perusahaan dengan residual income positif mampu meningkatkan kekayaan investor karena perusahaan tersebut akan mampu membayarkan dividen tunai kepada investor. Pasar akan merespon sinyal positif ini sehingga harga pasar saham perusahaan akan meningkat. Hal ini memungkinkan investor untuk mendapatkan capital gain. Oleh karena yield dan capital gain meningkat, maka stock return yang diterima investor juga mengalami peningkatan.

Pengaruh Market to Book Ratio terhadap Stock Return

Penelitian ini berhasil membuktikan bahwa market to book ratio secara signifikan berpengaruh positif terhadap stock return. Hasil penelitian ini mendukung beberapa penelitian terdahulu yang juga memberikan hasil serupa (Arista 2012; Margaretha dan Damayanti 2008; Nathaniel 2008; Putri 2012; Tinneke 2007).

Perusahaan dengan tingkat pengembalian ekuitas yang relatif tinggi biasanya akan menjual saham dengan perkalian yang lebih besar jika dibandingkan dengan perusahaan yang tingkat pengembalian ekuitasnya rendah. Hal ini mengindikasikan bahwa dengan tingkat pengembalian ekuitas yang lebih tinggi, perusahaan akan mampu menjual saham dengan nilai yang lebih tinggi dari nilai bukunya. Jika hal ini terus berlangsung, maka investor akan mendapatkan capital gain yang lebih baik sehingga stock return akan meningkat ( Brigham dan Houston 2009).

Semakin tinggi nilai market to book ratio menunjukkan bahwa harga pasar per lembar saham lebih tinggi dari nilai yang diinvestasikan pemegang saham. Harga pasar saham yang mengalami kenaikan akan memberikan peluang bagi investor untuk mendapatkan capital gain yang semakin tinggi. Oleh karena itu, stock return juga mengalami peningkatan.

Rata-rata perusahaan manufaktur di Indonesia memiliki nilai market to book ratio di atas 1 dimana hal ini mengindikasikan bahwa kinerja perusahaan manfaktur dapat dikatakan baik. Ketika harga pasar saham melebihi nilai bukunya, investor memandang bahwa pendapatan di masa yang akan datang lebih besar dari nilai likuidasi perusahaan (Margaretha dan Damayanti 2008). Dengan demikian, investor dapat menggunakan market to book ratio sebagai tolak ukur untuk mendapatkan stock return yang lebih tinggi dikemudian hari.

\section{KESIMPULAN DAN SARAN}

Berdasarkan hasil penelitian dan pembahasan diperoleh kesimpulan sebagai berikut: (1) residual income berpengaruh positif dan signifikan 
terhadap stock return, (2) market to book ratio berpengaruh positif dan signifikan terhadap stock return, dan (3) Variabel yang memberikan pengaruh paling besar terhadap stock return adalah market to book ratio.

Penelitian ini memberikan implikasi kepada manajemen perusahaan dan investor. Mengingat residual income dan market to book ratio secara individual berpengaruh positif signifikan terhadap stock return, maka manajemen perlu berusaha meningkatkan nilai residual income dan market to book ratio. Manajemen hendaknya berusaha mencapai residual income yang bernilai positif karena dengan demikian kemakmuran investor akan bertambah. Manajemen juga perlu merumuskan strategi supaya nilai market to book ratio bisa lebih besar daripada 1 karena hal ini menunjukkan kinerja perusahaan baik. Oleh karena itu, penting bagi manajemen untuk selalu bisa memperlihatkan profitabilitas yang tinggi dan menjaga nama baik perusahaan. Sedangkan, dari sisi investor, investor utamanya bisa menggunakan market to book ratio sebagai pertimbangan pertama dalam melakukan investasi saham. Selain itu, oleh karena residual income juga terbukti berpengaruh positif terhadap stock return, investor juga bisa menggunakan residual income sebagai tolak ukur dari stock return yang akan diterima investor.
Penelitian ini memiliki beberapa keterbatasan. Keterbatasan utama terletak pada digunakannya data akuntansi yang bersifat historis. Penelitian mungkin memberikan hasil yang berbeda jika data yang digunakan adalah data yang bersifat proyeksi. Data proyeksi seringkali lebih menggambarkan ekspektasi dari investor atas return yan diterima dikemudian hari. Selain itu, residual income dan market to book ratio yang digunakan sebagai prediktor stock return hanya mampu menjelaskan pengaruh secara bersamasama sebesar $55,1 \%$ sehinggavariasi stock return masih bisa dipengaruhi oleh $44,9 \%$ faktor lain di luar residual income dan market to book ratio. Keterbatasan lain terletak pada perhitungan komponen yield yang hanya menggunakan dividen kas saja, periode penelitian terbatas selama tiga periode, dan jumlah sampel yang relatif kecil.

Atas dasar keterbatasan tersebut, beberapa saran yang dapat diberikan dari penelitian ini adalah: (1) Penelitian selanjutnya sebaiknya menambah beberapa variabel lain yang diperkirakan mempengaruhi stock return, baik itu berupa faktor fundamental maupun faktor eksternal, (2) Penelitian selanjutnya sebaiknya bisa memperpanjang periode penelitian dan menambah jumlah sampel sehingga dapat diperoleh hasil penelitian yang lebih akurat, dan (3) Penelitian selanjutnya diharapkan bisa melakukan 
studi komparasi mengenai stock return pada perusahaan di Indonesia dengan perusahaan di negara lain sehingga investor bisa mengambil keputusan mengenai tempat berinventasi yang akan memberikan stock return maksimal bagi mereka.

\section{DAFTAR PUSTAKA}

Ang, R. (1997). Buku Pintar Pasar Modal Indonesia. Jakarta: Rineka Cipta.

Arista, D. (2012). Analisis Faktor-Faktor yang Mempengaruhi Return Saham (Kasus pada Perusahaan Manufaktur yang Go Public di BEI Periode Tahun 2005-2009), Jurnal Ilmu Manajemen dan Akuntansi Terapan, 3(1), 1-15.

Brigham, E.F., and Houston, J.F. (2009). Fundamentals of Financial Management, Tenth Edition. Fort Worth: The Dryden Press.

Bursa Efek Indonesia (19 Maret 2014), "Equity Daily Trading Publication", $w w w . i d x . c o . i d / e n-$ us/home/publication/statistic.aspx

Dewi, V.I. (2005). Analisis Pengaruh Faktor Fundamental dan Volume Perdagangan terhadap Total Return (Studi Empiris di Bursa Efek Jakarta), [Thesis], Semarang: Universitas Diponegoro.

Effendi, M.I., dan Muafi. (2001). CAPM: Berbagai Kajian Terhadap Model dan Peranannyadalam Pengukuran
Kinerja Portofolio, Usahawan, XXXX(07).

Fama, E.F., and French, K.R. (1995). The Cross Section of Expected Stock Returns, Journal of Finance, 47, 247265.

Fitriani. (2001). Signifikansi Perbedaan Tingkat Kelengkapan Pengungkapan Wajib dan Sukarela pada Laporan Keuangan Perusahaan Publik yang Terdaftar di Bursa Efek Jakarta. Makalah Simposium Nasional Akuntansi IV, Universitas Padjajaran dan Ikatan Akuntan Indonesia, Bandung.

Gitman, J.L. (2009). Principles of Managerial Finance, $12^{\text {th }}$ edition. USA: Pearson Education Inc.

Gitman, J.L., and Joehnk, M.D. (2008). Fundamentals of Investing, 10 $0^{\text {th }}$ Edition. USA: Pearson Education Inc.

Halim, A. (2005). Analisis Investasi, Edisi Kedua. Jakarta: Salemba Empat.

Hartono, J. (2010). Teori Portofolio dan Analisis Investasi. Yogyakarta: BPFE.

Husnan, S., dan Hermanto, S. (1998). CAPM dan Strategi Portofolio: Kajian Kondisi Pasar di BEJ 1997, Usahawan, XXVII(5).

Kieso, D.E., Weygandt, J.J., \& Warfield, T.D. (2011). Intermediate Accounting: IFRS Edition. New Jersey: John Wiley \& Sons, Inc. 
Mardani, R.M. (2013). Pengaruh Earnings, Residual Income, Economic Value Added dan Operation Cash Flow terhadap Return Saham, Iqtishoduna, 9(1), 1-20.

Margaretha, F., dan Damayanti, I. (2008).

Pengaruh Price Earning Ratio,

Dividend Yield, dan Market to Book Ratio terhadap Stock Return di Bursa Efek Indonesia, Jurnal Bisnis dan Akuntansi, 10(3), 149-160.

Martono, N.C. (2009). Pengaruh Faktor

Fundamental Perusahaan dan Nilai

Tukar terhadap Return Saham pada

Perusahaan yang Terdaftar di BEI (Kasus pada Perusahaan Manufaktur Periode Tahun 20032007), [Thesis], Semarang: Universitas Diponegoro.

Nathaniel, N. (2008). Analisis Faktor-

Faktor yang Mempengaruhi Return

Saham (Studi pada Saham-Saham

Real Estate dan Properti di Bursa

Efek Indonesia Periode 2004-2006.

[Tesis], Semarang: Universitas Diponegoro.

Pradhono dan Christiawan, Y.Y. (2004). Pengaruh Economic Value Added, Residual Income, Earnings dan Arus Kas Operasi terhadap Return yang Diterima oleh Pemegang Saham, Jurnal Akuntansi dan Keuangan, 6(2), 140-166.

Prasetya, T. (2000). Analisis Rasio Keuangan dan Nilai Kapitalisasi
Pasar sebagai Prediksi Harga Saham di BEJ pada Periode Bullish dan Bearish. Makalah Simposium Nasional Akuntansi III, Kompartemen Akuntan Publik, Depok, 20 September.

Putri, A.A.B. (2012). Analisis Pengaruh ROA, EPS, NPM, DER, dan PBV terhadap Return Saham (Studi Kasus pada Industri Real Estate dan Properti yang Terdaftar di Bursa Efek Indonesia Periode 2007-2009), [Skripsi], Semarang: Universitas Diponegoro.

Ross, S.A., Westerfield, R.W., and Jaffe, J. (2002). Corporate Finance, $6^{\text {th }}$ Edition. New York: Mc. Graw-Hill.

Sartono, A. (2001). Manajemen Keuangan Teori dan Aplikasi, Edisi Keempat. Yogyakarta: BPFE.

Siegel, J.G., and Shim, J.K. (2000). Dictionary of Accounting Terms. New York: Barron's

Sugiyono. (2011). Metode Penelitian Administrasi Dilengkapi dengan Metode RED. Bandung: Alfabeta.

Tandelilin, E. (2007). Analisis Investasi dan Manajemen Portofolio. Yogyakarta: BPFE Yogyakarta.

Tinneke, R. (2007). Analisis Pengaruh Economic Value Added (EVA) dan Faktor-Faktor Fundamental Perusahaan Lainnya terhadap Return Saham (Studi Empiris pada 
Perusahaan Sektor Industri

Manufaktur di Bursa Efek Jakarta),

[Thesis], Semarang: Universitas Diponegoro.

Tiswiyati, W. (2011). Pengaruh Economic

Value Added (EVA), Residual

Income, Earning, dan Arus Kas

Operasi terhadap Return yang

Diterima Pemegang Saham pada

Perusahaan LQ 45 Tahun 2008-2009,

Jurnal Penelitian Universitas Jambi Seri

Humaniora, 13(1), 41-46.

Tjiptono, D., dan Hendy, D. (2006). Pasar

Modal Indonesia: Pendekatan Tanya

Jawab. Jakarta: Salemba Empat.

Trisnawati, I. (2009). Pengaruh Economic Value Added, Arus Kas Operasi, Residual Income, Earnings,

Operating Leverage dan Market
Value Added terhadap Return Saham, Jurnal Bisnis dan Akuntansi, 11(1), 65-78.

Utama, S., dan Yulianto, B.S. (1998). Kaitan antara Rasio PBV dan Imbal Hasil Saham pada BEJ, Jurnal Riset Akuntansi Indonesia, 1(1), 127-140.

Weston, J.F., and Copeland, T.E. (1995), Managerial Finance, New York: NCBS College Publishing.

Yudhira, A. (2008). Pengaruh Economic Value Added, Residual Income, Earnings, dan Cash Flow Operation terhadap Stock Return pada Perusahaan Manufaktur di Bursa Efek Jakarta Tahun 2001-2006, [Thesis], Medan: Universitas Sumatera Utara. 
